\title{
PRESENCE OF EISENIA FETIDA ENHANCED PHYTOREMEDIATION OF ANTHRACENE BY LOLIUM PERENNE
}

\author{
PRESENÇA DE EISENIA FETIDA AUMENTOU A FITORREMEDIAÇÃO DO \\ ANTRACENO POR LOLIUM PERENE
}

\author{
Akbar GHAVIDEL ${ }^{1}$; Sumayyah Naji RAD² ; Hossein Ali ALIKHANI $^{3}$; \\ Bagher YAKHCHALI ${ }^{4}$; Ahmad Ali POURBABAI ${ }^{3}$; \\ 1. University of Mohaghegh Ardabili, Department of Soil Science and Engineering, Ardabil, Iran. Ghavidel@uma.ac.ir; \\ 2. Young Researchers and Elite Club, Ardabil Branch, Islamic Azad University, Ardabil, Iran; University of Tehran, \\ Department of Soil Science and Engineering, Karaj, Iran; 3. National Institute of Genetic Engineering and Biotechnology, \\ Tehran, Iran.
}

\begin{abstract}
The efficiency of co-application of Eisenia fetida and ryegrass was evaluated in a process called earthworm-assisted phytoremediation. Anthracene was used as a model compound for polycyclic aromatic hydrocarbons (PAHs). The experiments were conducted on a loamy soil in greenhouse conditions. At the end of the experiment, the soil samples were analyzed for residual anthracene by HPLC. Results showed that, phytoremediation using ryegrass could remove $81 \%$ of anthracene; however, the rate of removal was $92 \%$ when E. fetida was applied simultaneously. E. fetida alone could also remove the initial concentration of anthracene by $40 \%$. Although ryegrass itself could remove anthracene significantly, the employment of earthworm, together with plant was more efficient than each of them individually. The application of $E$. fetida could also enhance the growth parameters of ryegrass significantly. In comparison to the control, the presence of E. fetida increased plant dry weight (7.8\%), root length (47\%), shoots length (32\%), and root volume $(12 \%)$. The number of live earthworms was also increased in the planted pots, indicating the helpfulness of the plant for survival of the earthworm in the PAH-contaminated soil. Although plant and earthworm use completely different mechanisms for anthracene degradation, they improve efficiency and survival of the three-component-system.
\end{abstract}

KEYWORDS: Anthracene, bioremediation, Earthworm, Lolium perenne, PAHs, Earthworm-assisted Phytoremediation

\section{INTRODUCTION}

Hydrocarbons are among the most challenging soil contaminants. Some of the hydrocarbons are easily degradable by indigenous soil microflora. However, some of the hydrocarbons are problematic, as they are recalcitrant and remain in the soil for a long time (PENG et al., 2008). In recent decades, with the increased awareness of their potential toxicity to human health, the remediation of lands contaminated with these compounds, has received increasing attention.

Polycyclic aromatic hydrocarbons (PAHs) are ubiquitous environmental pollutants, which are of serious concern due to their potential toxicity, mutagenicity, and carcinogenicity (PENG et al., 2008). PAHs consist of two or more benzene rings, which are fused in different structural conformations. The hydrophobicity, recalcitrance, and toxicity of PAHs increases as the number of benzene rings increases (KANALY; HARAYAMA, 2000). These compounds occur naturally in the environment; however, human activities are their main source. Incomplete combustion of organic compounds, such as fuels and trees in forest fires, results in the production of PAHs (HARITASH; KAUSHIK, 2009). The estimations imply that most of the total environmental $\mathrm{PAH}$ is found in terrestrial ecosystems, specifically, in the top soil which is the ultimate depository of these pollutants (MROZIK et al., 2003). They persist in the environment due to low aqueous solubility and high adsorption on the soil particles. As a result of these properties, the half-lives of PAHs vary from 1 week to 2 months in aquatic environments and 2 months to 2 years in soils (SVERDRUP et al., 2003). The persistence of PAHs in contaminated soil poses a considerable risk to human health, because they can possibly enter into the food chain. Therefore, remediation of these compounds from soil should be retained.

Anthracene is a tricyclic aromatic hydrocarbon which is found in PAH-contaminated environments. It is considered as a model PAH, since its chemical structure is observed in dangerous and carcinogenic PAHs, such as benzo[ $\alpha]$ anthracene (KANALY; HARAYAMA, 2000; MROZIK et al., 2003).

Ryegrass has been used in many $\mathrm{PAH}$ phytoremediation studies (BINET et al., 2001) 
possibly due to its comparatively rapid growth, extensive root system and the ability to cope with high concentrations of PAHs. Ryegrass has also been used for phytoremediation of heavy metals from metal contaminated soils (TAKÁCS et al., 2001). Phytoremediation is the use of plants (such as ryegrass) and their associated microorganisms to extract, degrade, or sequester organic and inorganic pollutants in/from soil (PARRISH et al., 2006). Due to its cost-effective and environmentally-friendly features, phytoremediation is becoming a valuable technology in soil clean-up programs (MURATOVA et al., 2008). Although the ability of plants to remove PAHs from soil is well documented (PARRISH et al., 2004), the efficacy of phytoremediation varies greatly depending on soil and environmental conditions (ROBSON et al., 2003) and the physico-chemical nature of the contaminant (ALEXANDER, 1999). In this regard, earthworm has a great potential in enhancing plant growth by several different mechanisms (SCHEU, 2003) including positive effects on the population of rhizospheric prokaryotes, which are involved in PAHs degradation (HICKMAN; REID, 2008).

Earthworms have beneficial influences on plants; they could increase available nutrients, improve soil physical conditions such as structure and aeration, and increase plant biomass (EDWARDS, 2004). Earthworms also excrete mucus, which can be easily metabolized by bacteria and subsequently boost bacterial population (SCHEU, 2003). Therefore, the presence of earthworms enhances the PAHdegradation in the contaminated soils by positively affecting two main factors, which are involved in the process of PAH-biodegradation. Moreover, they are able to make soil conditions tolerable especially for plant that is typically more sensitive to PAHs, than bacteria. For example, they accumulate organic pollutants from the surrounding soil (BELFROID et al., 1995) thereby reducing their availability for plant roots (PARRISH et al., 2006).

Earthworms are also able to involve directly in degradation of PAHs. Studies have shown that annelids, such as aquatic polychaetes, can metabolize benzo(a)pyrene, due to their cytochrome $\mathrm{P} 450$ enzymes which initiate degradation of this component (KANE DRISCOLL; McELROY, 1997). Terrestrial earthworms such as Eisenia fetida also possess the same enzymatic activity (ÁLVAREZ-BERNAL et al., 2006; CONTRERAS-RAMOS et al., 2008).
Therefore, the presence of the earthworms can possibly increase the rate of phytoremediation.

We aimed to investigate the effect of $E$. fetida as an effective species on the phytoremediation of anthracene by ryegrass.

\section{MATERIALS AND METHODS}

\section{Soil Preparation}

A loamy soil was sampled from the top 20 $\mathrm{cm}$ from agricultural soils near Shahryar city, Tehran Province $\left(35^{\circ} 31^{\prime} 41^{\prime \prime} \mathrm{N}\right.$ and $51^{\circ} 25^{\prime} 13^{\prime \prime}$ E). It was air-dried and sieved (40 mesh, <2mm) and stored at $4^{\circ} \mathrm{C}$ until use. The soil samples were analyzed chemically by standard methods (SPARKS et al., 1986).

\section{Phytoremediation experiments}

The soil was spiked with anthracene via three steps as follows. i) $1 \mathrm{~g}$ of anthracene was dissolved in acetone and sprayed into $100 \mathrm{~g}$ of soil and mixed thoroughly. ii) The spiked soil was left uncovered under a fume hood for $48 \mathrm{~h}$ allowing acetone to be evaporated off from the soil. iii) The spiked samples were then mixed with the remaining $900 \mathrm{~g}$ of soil (BINET et al., 2001). Then the final concentration of anthracene was 1000 mg. $\mathrm{kg}^{-1}$. After adding anthracene, the pots were stored at room temperature for two months, allowing anthracene to be adsorbed on soil particles (aging). Prior to planting, the seeds of ryegrass (Lolium perenne L.) were disinfected in ethanol and sodium hypochlorite for $15 \mathrm{~min}$, and then rinsed three times with the sterile distilled water. The seeds were germinated in water and the seedlings were transferred to the pots. Four seedlings were grown in each pot. In order to avoid nutrient deficiency, each pot was supplied with $\mathrm{KH}_{2} \mathrm{PO}_{4}$ and $\mathrm{NH}_{4} \mathrm{NO}_{3}$ based on the soil analysis results (NAJIRAD et al., 2013). Adult earthworms (E. fetida) with developed clitellum, were selected manually from a vermicompost farm before the experiments. For the treatments, which include earthworms, 10 adult earthworms were added to each of the pots. The pots were maintained in greenhouse $\left(25 \pm 3^{\circ} \mathrm{C}\right)$ for 90 days. The pots were irrigated with distilled water to maintain soil moisture at $50-70 \%$ of field capacity. After 90 days, a soil sample of $25 \mathrm{~g}$ of each pot was extracted using Soxhlet extractor for $24 \mathrm{~h}$ using $250 \mathrm{ml}$ mixture of acetone and normal hexane (1:1 $\mathrm{v} / \mathrm{v}$ ) as a solvent. The extract was then eluted via a $\mathrm{Na}_{2} \mathrm{SO}_{4}$ column to remove water and salts from the extract. The extract was then used for HPLC analysis. 


\section{Plant and earthworm parameters}

The plant roots were washed by tap water followed by washing with distilled water. The wiped plants fresh weight was measured using a balance and the root and shoot parts were cut. The length of roots and shoots were measured using a ruler for each of the plants and data were reported as average value per pot. The root volume was measured by volumetric method (CHEUNG et al., 2008). Then the root and shoot parts of each plant were put in a paper pocket and put in an oven at $70^{\circ} \mathrm{C}$ for $48 \mathrm{~h}$. Then the dry weight for root and shoot of each plant was weighted and the mean value for each pot was reported. The earthworms were also removed from the soil and live earthworms were counted manually, washed with distilled water, wiped and weighed (CONTRERAS-RAMOS et al., 2006).

\section{Experimental Design}

The statistical design was a completely randomized design. Four treatments were established: the plant treatment, the earthworm treatment, the treatment with both plant and earthworm, and a control without plant and earthworm. All treatments were established in four replicates.

\section{HPLC Analysis}

Anthracene concentrations were measured using a high performance liquid chromatography
(HPLC) with a Knover model K-2600 UV-detector and a $46-$ by $250-\mathrm{mm} 5-\mu \mathrm{m}$ C18 Inertsil ODS-3 column (Merck) (ZEINALI et al., 2008).

\section{Chemicals}

All chemicals were purchased from local retailer of Merck Company, Germany. The chemicals were of analytical grade.

\section{Statistical Analysis}

SPSS statistical software was used to statistically analyze the experimental data. To compare the means of treatments, one-way ANOVA was used, and the difference among the means were compared using Duncan's multiple range test $(p<0.05)$.

\section{RESULTS}

\section{Properties of Soil}

The texture of the soil was loamy which seems to be optimum for phytoremediation studies. Three macronutrients were measured in the samples (Table 1) and the deficiency of nitrogen was compensated for by the addition of $\mathrm{NH}_{4} \mathrm{NO}_{3}$ as a nitrogenous fertilizer. There was no other major problem with the rest of the macronutrients. The EC and $\mathrm{pH}$ values were not limiting; however, the $\mathrm{pH}$ value was relatively high (8.2).

Table 1. Some chemical and physical characteristics of the soil sample

\begin{tabular}{ll}
\hline Characteristic & Value \\
\hline Sand (\%) & $35 \pm 3$ \\
Silt (\%) & $40 \pm 3$ \\
Clay (\%) & $25 \pm 2$ \\
pH & $8.2 \pm 0.2$ \\
EC (dS/m) & $1.22 \pm 0.15$ \\
Organic carbon (\%) & $0.82 \pm 0.7$ \\
Kjeldahl nitrogen (\%) & $0.115 \pm 0.06$ \\
Olsen Phosphorus (mg.kg & $40.46 \pm 4$ \\
Potassium (mg.kg & $221 \pm 9$ \\
\hline
\end{tabular}

\section{Anthracene Degradation}

The two- and one-ringed compounds were not detected as shown in chromatograms indicating the complete degradation of anthracene in the soil. There was a significant difference $(\mathrm{p}<0.05)$ among the treatments regarding anthracene degradation (Figure 1). The phytoremediation of anthracene using $L$. perenne has led to $81 \%$ decrease in the soil anthracene compared to the initial amount. The application of E. fetida alone removed only $40 \%$ of the total anthracene. Meanwhile, the presence of $E$. fetida along with $L$. perenne was effective in removal of anthracene significantly $(p<0.05)$. It could increase the rate of removal when it was applied with the plant (L. perenne). The rate of removal was $92 \%$ when the earthworm and plant were applied as a single treatment (Fig 1). 
Microbial degradation has also taken place as revealed in the control. Results showed that nearly $390 \mathrm{mg} \cdot \mathrm{kg}^{-1}$ of initial amount of anthracene has disappeared from soil due to microbial and chemical degradations.

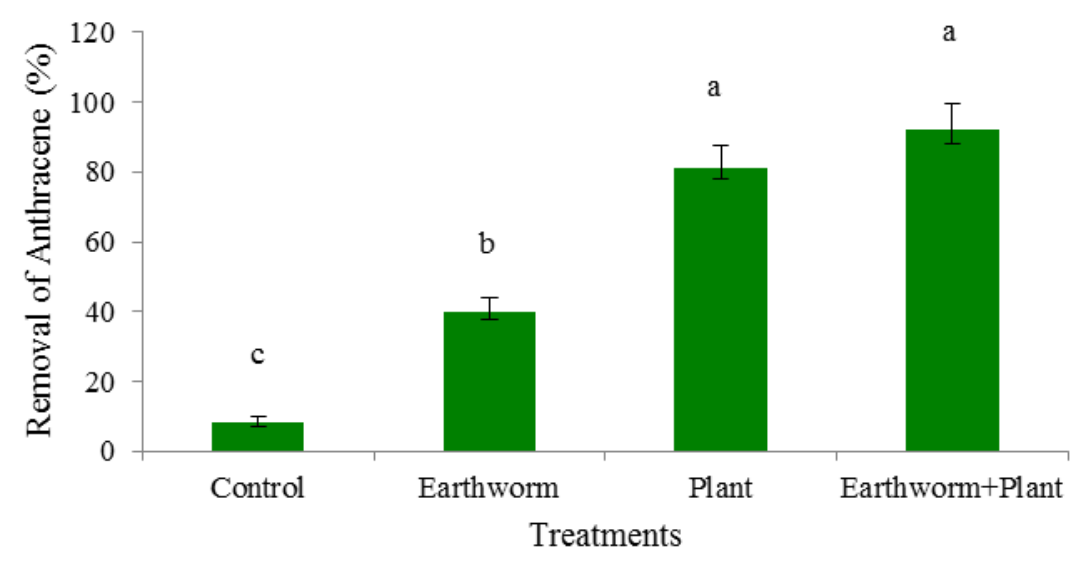

Figure 1. Removal of anthracene in different treatments

\section{Earthworm survival}

The number of live earthworms was counted in each pot after experiments. The viability of earthworms was significantly different $(\mathrm{p}<0.05)$ among the treatments (Figure 2). L. perenne could positively affect the survival of $E$. fetida in the presence of anthracene. The presence of plant was helpful on the survival of earthworm even in the control, which was not contaminated.

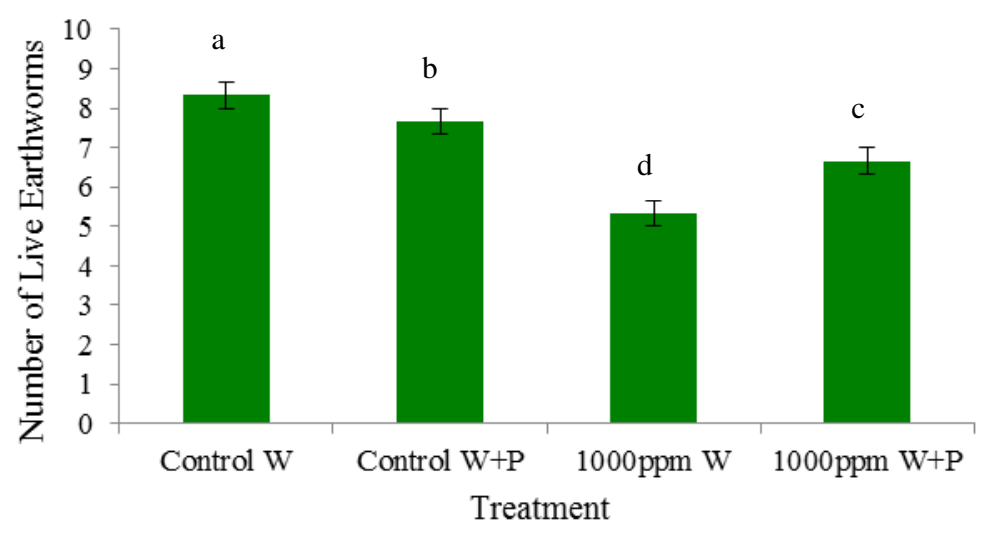

Figure 2. Effect of anthracene concentrations and presence of Lolium perenne on the number of live earthworms

(Control W: control with the addition of earthworms; Control W+P: the control which plant were cultivated and the earthworms were added; $1000 \mathrm{ppm} \mathrm{W}$ : The treatment with the earthworms with $1000 \mathrm{ppm}$ of anthracene concentration, $1000 \mathrm{ppm} \mathrm{W}+\mathrm{P}$ : The treatment which is cultivated by the plant and the earthworms were added earthworms with 1000ppm of anthracene concentration).

\section{Plant growth parameters}

The contamination of soil with anthracene had adverse effect on the growth parameters of $L$. perenne. Anthracene contamination significantly $(\mathrm{p}<0.05)$ decreased the length of roots (Figure 3$)$ as well as shoot (Figure 4). The contamination also had a harmful effect on the root volume (Figure 5). The root volume was significantly higher $(\mathrm{p}<0.05)$ when the earthworm was present in the pots (Fig. 5). Regarding root and shoot length, there was a significant difference $(\mathrm{p}<0.05)$ among the plants grown together with earthworms and the plants, which were grown alone. The presence of E. fetida had positively influenced the growth parameters of ryegrass (Fig 3 and 4 ). The plants, which were grown together with E. fetida, had longer roots and 
shoots. The contamination has affected the plant dry matter significantly $(\mathrm{p}<0.05)$. The presence of anthracene decreased the plant dry matter; meanwhile the presence of the earthworms has diminished the toxic effect of anthracene (Fig 6).

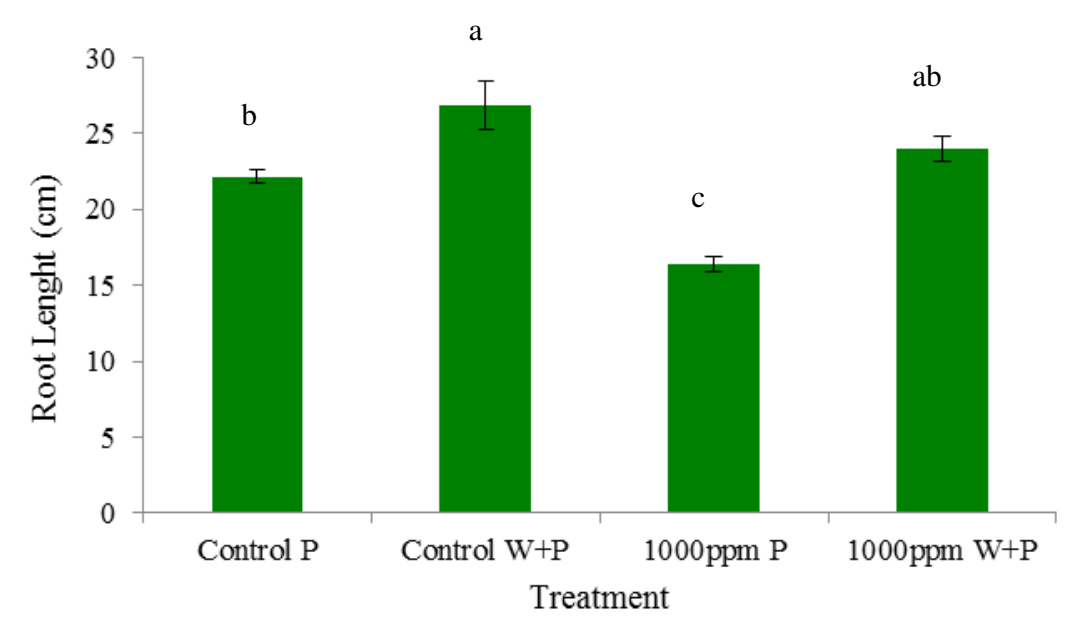

Figure 3. The effect of anthracene concentration and presence of Eisenia fetida on the root length of Lolium perenne

(Control P: control which plant were cultivated; Control W+P: the control which plant were cultivated and the earthworms were added; 1000ppm P: The treatment which plant were cultivated with 1000ppm of anthracene concentration, 1000ppm W+P: The treatment which is cultivated by the plant and the earthworms were added with 1000ppm of anthracene concentration).

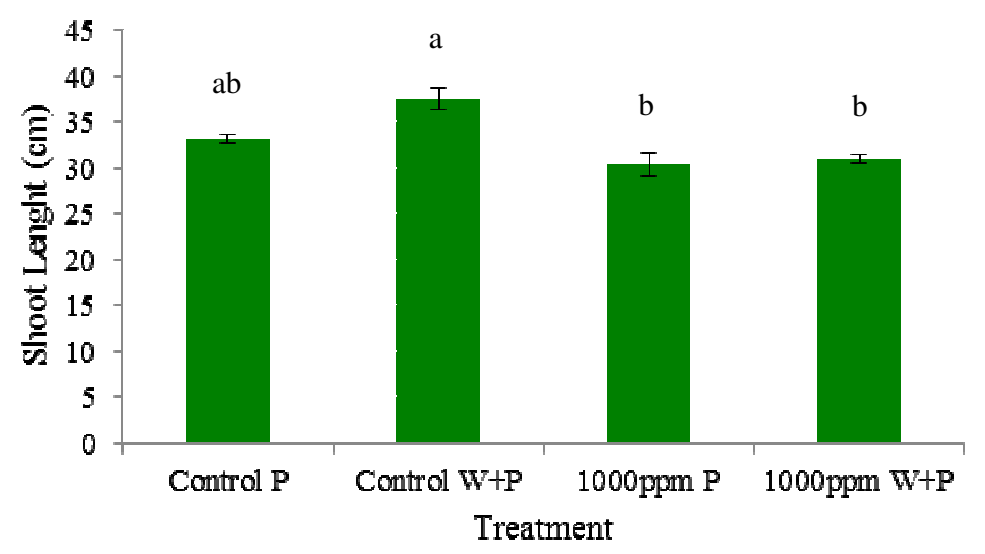

Figure 4. The effect of anthracene and Eisenia fetida on the shoot length of Lolium perenne

(Control P: control which plant were cultivated; Control W+P: the control which plant were cultivated and the earthworms were added; 1000ppm P: The treatment which plant were cultivated with 1000ppm of anthracene concentration, 1000ppm W+P: The treatment which is cultivated by the plant and the earthworms were added with $1000 \mathrm{ppm}$ of anthracene concentration). 


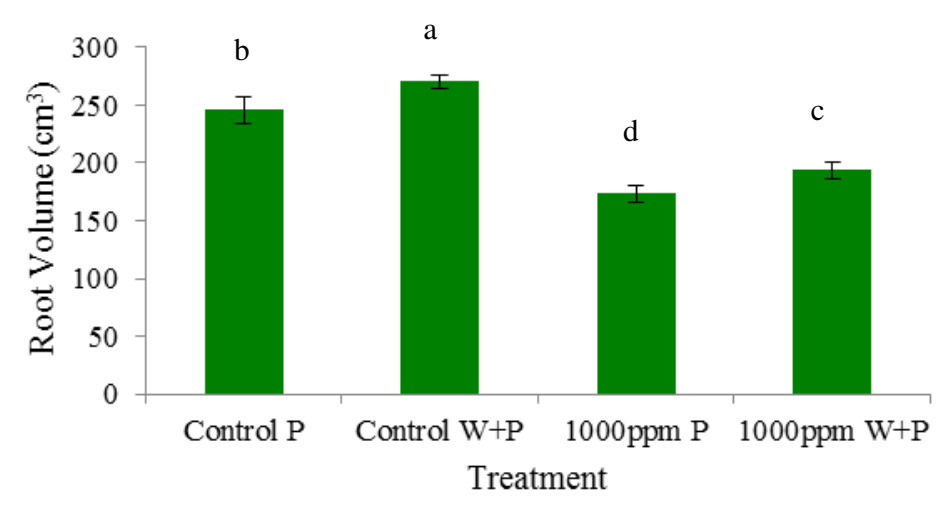

Figure 5. The effect of anthracene and Eisenia fetida on the root volume of Lolium perenne

(Control P: control which plant were cultivated; Control W+P: the control which plant were cultivated and the earthworms were added; 1000ppm P: The treatment which plant were cultivated with 1000ppm of anthracene concentration, 1000ppm W+P: The treatment which is cultivated by the plant and the earthworms were added with 1000ppm of anthracene concentration).

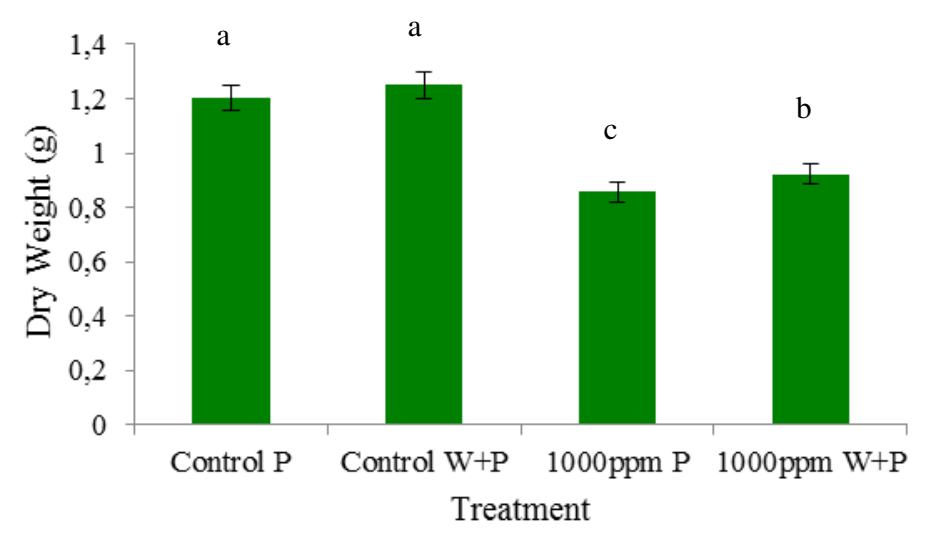

Figure 6. The effect of anthracene and Eisenia fetida on the dry weight of Lolium perenne

(Control P: control which plant were cultivated; Control W+P: the control which plant were cultivated and the earthworms were added; $1000 \mathrm{ppm}$ P: The treatment which plant were cultivated with 1000ppm of anthracene concentration, 1000ppm W+P: The treatment which is cultivated by the plant and the earthworms were added with 1000ppm of anthracene concentration).

\section{DISCUSSION}

L. perenne has revealed a satisfactory anthracene remediation in the soil. Regarding the rate of removal $(81 \%)$, L. perenne seems to be one of the most efficient plants in phytoremediation of anthracene from soil. Given that anthracene is used as a model compound for PAHs (KANALY; HARAYAMA, 2000; MROZIK et al., 2003), it can be concluded that this plant could be used as an appropriate plant species to remediate the soils contaminated with such compounds. Others have observed almost the same removal rate of PAHs (BINET et al., 2000) by L. perenne. These results along with other observations (BINET et al., 2000, 2001) demonstrate the potential of this plant in phytoremediation studies. Some studies (LIN et al., 2006; WANG et al., 2006; DANDAN et al., 2007) have also used other members of the genus Lolium, such as Lolium multiflorum in phytoremediation of heavy metals.

Rhizodegradation mainly involves soil microorganisms. It is an intensive interaction between plant root and rhizospheric microorganisms. There are many soil microorganisms whose ability in PAH degradation has been well studied (DOYLE et al., 2008). Plant growth and development increases the root exudates and enhances the activity of surrounding microorganism which consequently enhances the degradation.

E.fetida has been used in several studies due to their ability to deal with the toxic organic 
compounds (CONTRERAS-RAMOS et al., 2006; BIANCHI; CECCANTI, 2010b). This ability enables those earthworms to tolerate high concentrations of contaminants, which were otherwise fatal to the earthworms. The results indicated that this earthworm could remove almost $40 \%$ of anthracene when applied as a treatment to the contaminated soils (COUTIÑOGONZÁLEZ et al., 2010). However, studies have shown that E. fetida accumulates PAHs in their body (PARRISH et al., 2006), that is the reason for their death at high concentrations of PAHs. It appears to be a suitable option for this kind of studies since they are also beneficial in making some improvements in soil properties. It means that after remediation process, some of the physical and chemical properties of the soil will be improved preparing the soil for the next step of treatments.

The earthworms could also increase available nutrients in soil, and consequently, increase plant biomass (EDWARDS, 2004). According to the results of the present study, $E$. fetida has significantly increased the dry matter of L. perenne (Fig. 6). Due to the increase in the quality of plant development, the dry matter increased. In addition, the roots are longer when the earthworms are present in the treatments (Fig. 3), indicating the effect of earthworm in increasing soil porosity and aeration. It is well known that as the porosity of a soil increases, the roots encounter less resistance, thus they could develop and go further. All of these changes are beneficial for plant growth, root development, and elongation. The effect of earthworm on the root length in the control showed that the earthworm increased the root length of $L$. perenne. They have also enhanced plant growth parameter such as plant dry matter, shoot length, and root volume. It means that $E$. fetida improves the capabilities of L.perenne in phytoremediation of anthracene. The earthworm has also affected the ability of plant to cope with the contamination which is one of the most important capabilities of plants used for phytoremediation. It makes plant to be able to tolerate higher concentrations of a contaminant. It is obvious that in the treatment with the earthworm, the plants could grow and develop better in comparison to the treatment without the earthworm.

The results demonstrate even a more important point that, if the earthworm (E. fetida) and the plant (L.perenne) are applied to the soil simultaneously, the rate of anthracene removal will be more than when they are applied alone. It means that the efficiency of plant and earthworm increases when the other partner is present in the environment. The efficiency of a plant in phytoremediation process depends on its growth and development. The higher the development and growth, the higher degradation rate can be achieved. Therefore, if a factor alters the environmental conditions for a plant, the phytoremediation efficiency will be changed consequently. The mechanism of the synergy between plant and earthworm has been studied previously; however, little knowledge is available about the contribution of plant and earthworm to the removal of organic contaminants. Generally, any modification in the environment can possibly change the rate of remediation for both plant and earthworm. Earthworms are believed to have beneficial chemical and physical impacts on soil. These improvements affect the plant growth and development, which subsequently increase the ability of the plant to clean-up soil (XIAO et al., 2010). Accordingly, any improvements, which are made by a plant, affect the activity and survival of earthworms (Fig. 2). Plants can influence the bioavailability of pollutants to earthworms via a variety of processes including uptake, volatilization, metabolism, and stimulation of microbial degradation (PILONSMITS, 2005). As shown in Fig. 2, the viability of $E$. fetida increased in the treatments which include cultivation of plant. The presence of $L$. perenne helps E. fetida to tolerate higher concentrations of anthracene; the same is done by the plant on the earthworm.

Soil microorganism is another important factor in this system. The soil samples were taken from the PAH-contaminated land, which had been exposed, to such contaminants for many years. Thus, the soil samples are supposed to have relatively high population of microorganisms, which are involved in biodegradation of PAHs. The role of the microorganisms, in this study can be observed in the control treatment. As the initial concentration of anthracene was $1000\left(\mathrm{mg}^{\mathrm{kg}} \mathrm{kg}^{-1}\right)$, the difference between anthracene concentration in control treatment and the initial concentration can be attributed to the biodegradation by microorganisms. Therefore, the soil system is a complex environment, which is composed of these three components (plant, earthworm, and microorganisms). As previously discussed (BIANCHI; CECCANTI, 2010a), any of these 
components have a unique relationship with each other; besides, each of these components has its own function on biodegradation of the contaminant. They also mentioned that any changes, which affect each of the components, could subsequently affect the accumulative degradation process.

\section{CONCLUSION}

The results indicate that co-application of L. perenne and E. fetida is more efficient in the removal of anthracene than the application of each of them alone. Although the phytoremediation of anthracene can be achieved successfully using $L$. perenne, the addition of $E$. fetida, increased the degradation rate to $92 \%$. This increase is the result of mutualism between L. perenne and E. fetida. Although plant and earthworm use completely different mechanisms for anthracene degradation, earthworm enhances phytoremediation by improving plant growth, development and survival in the contaminated soil.

The time required for phytoremediation practices is one the factors which limits its
GHAVIDEL, A. et al.

application over bioremediation (microbial remediation) since phytoremediation takes more time than bioremediation. The application of earthworms as an improvement for the phytoremediation process decreases the time required for phytoremediation.

Furthermore, the activity of earthworm improves soil properties over time, which is a simultaneous treatment of a contaminated soil. As the earthworm assisted phytoremediation finishes, the treated soil will have more suitable conditions than the untreated soil.

In addition, co-application of a plant and an earthworm allows us to use their degradation capabilities on the higher concentration of a contaminant, since they increase each other's tolerance to any given contaminant.

\section{ACKNOWLEDGMENT}

This study was part of a Ph.D. thesis in University of Tehran, and financially supported by University of Tehran and National Institute of Genetic Engineering and Biotechnology.

RESUMO: A eficiência da co-aplicação de Eisenia fetida e azevém foi avaliada em um processo denominado fitorremediação assistida por minhocas. $\mathrm{O}$ antraceno foi usado como um composto modelo para hidrocarbonetos aromáticos policíclicos (PAHs). Os experimentos foram conduzidos em um solo argiloso em condições de estufa. No final da experiência, as amostras de solo foram analisadas quanto ao antraceno residual por HPLC. Os resultados mostraram que, a fitorremediação com azevém pode remover $81 \%$ do antraceno; no entanto, a taxa de remoção foi de 92\% quando E. fetida foi aplicada simultaneamente. E. fetida sozinha também foi capaz de remover a concentração inicial de antraceno em $40 \%$. Embora o próprio azevém pudesse remover significativamente o antraceno, o emprego da minhoca, juntamente com a planta, foi mais eficiente do que cada um deles individualmente. A aplicação de E. fetida também pode melhorar significativamente os parâmetros de crescimento do azevém. Em comparação com o controle, a presença de E. fetida aumentou o peso seco da planta $(7,8 \%)$, o comprimento da raiz $(47 \%)$, o comprimento da parte aérea $(32 \%)$ e o volume radicular (12\%). O número de minhocas vivas também aumentou nos vasos plantados, indicando a utilidade da planta para a sobrevivência da minhoca no solo contaminado com PAH. Embora plantas e minhocas usem mecanismos completamente diferentes para a degradação do antraceno, eles melhoram a eficiência e a sobrevivência do sistema de três componentes. minhoca

PALAVRAS-CHAVE: Antraceno. Biorremediação. Minhoca. Lolium perenne. PAHs. Assistida por

\section{REFERENCES}

ALEXANDER, M., Biodegradation and Bioremediation. Academic Press, 1999. 453 p.

ÁLVAREZ-BERNAL, D.; GARCÍA-DÍAZ, E. L.; CONTRERAS-RAMOS, S. M.; DENDOOVEN, L. Dissipation of polycyclic aromatic hydrocarbons from soil added with manure or vermicompost.

Chemosphere, v. 65, p. 1642-1651, 2006. https://doi.org/10.1016/j.chemosphere.2006.02.028 
BELFROID, A.; MEILING, J.; DRENTH, H. J.; HERMENS, J.; SEINEN, W.; VAN GESTEL, K. Dietary uptake of superlipophilic compounds by earthworms (Eisenia andrei). Ecotoxicology and Environmental Safety, v. 31, p. 185-191, 1995. https://doi.org/10.1006/eesa.1995.1061

BIANCHI, V.; CECCANTI, B. A three components system (TRIAS) in the phytoremediation of polluted environmental matrices. Toxicological \& Environmental Chemistry, v. 92, p. 477-493, 2010a. https://doi.org/10.1080/02772240903036154

BIANCHI, V.; CECCANTI, B. A three components system (TRIAS) in the phytoremediation of polluted environmental matrices. Toxicological and Environmental Chemistry, v. 92, p. 477-493, 2010b. https://doi.org/10.1080/02772240903036154

BINET, P.; PORTAL, J. M.; LEYVAL, C.; Dissipation of 3-6-ring polycyclic aromatic hydrocarbons in the rhizosphere of ryegrass. Soil Biology and Biochemistry, v. 32, p. 2011-2017, 2000.

https://doi.org/10.1016/S0038-0717(00)00100-0

BINET, P.; PORTAL, J. M.; LEYVAL, C. Application of GC-MS to the study of anthracene disappearance in the rhizosphere of ryegrass. Organic Geochemistry, v. 32, p. 217-222, 2001. https://doi.org/10.1016/S01466380(00)00168-6

CHEUNG, K. C.; ZHANG, J. Y.; DENG, H.H.; OU, Y. K.; LEUNG, H. M.; WU, S. C.; WONG, M. H. Interaction of higher plant (jute), electrofused bacteria and mycorrhiza on anthracene biodegradation. Bioresource Technology, v. 99, p. 2148-2155, 2008. https://doi.org/10.1016/j.biortech.2007.05.037

CONTRERAS-RAMOS, S. M.; ALVAREZ-BERNAL, D.; DENDOOVEN, L. Removal of polycyclic aromatic hydrocarbons from soil amended with biosolid or vermicompost in the presence of earthworms (Eisenia fetida). Soil Biology \& Biochemistry, v. 40, p. 1954-1959, 2008. https://doi.org/10.1016/j.soilbio.2008.04.009

CONTRERAS-RAMOS, S. M.; ÁLVAREZ-BERNAL, D.; DENDOOVEN, L. Eisenia fetida increased removal of polycyclic aromatic hydrocarbons from soil. Environmental Pollution, v. 141, p. 396-401, 2006. https://doi.org/10.1016/j.envpol.2005.08.057

COUTIÑO-GONZÁLEZ, E.; HERNÁNDEZ-CARLOS, B.; GUTIÉRREZ-ORTIZ, R.; DENDOOVEN, L. The earthworm Eisenia fetida accelerates the removal of anthracene and 9, 10-anthraquinone, the most abundant degradation product, in soil. International Biodeterioration and Biodegradation, v. 64, p. 525-529, 2010. https://doi.org/10.1016/j.ibiod.2010.05.002

DANDAN, W.; HUIXIN, L.; FENG, H.; XIA, W. Role of earthworm-straw interactions on phytoremediation of Cu contaminated soil by ryegrass. Acta Ecologica Sinica, v. 27, p. 1292-1298, 2007.

https://doi.org/10.1016/S1872-2032(07)60030-4

DOYLE, E.; MUCKIAN, L.; HICKEY, A. M.; CLIPSON, N. Microbial PAH Degradation. In: LASKIN, A.I.; SARIASLANI, S.; GADD, G.M. (Ed.) Advances in Applied Microbiology, San Diego, CA: Elsevier, 2008. p. 27-66. https://doi.org/10.1016/S0065-2164(08)00602-3

EDWARDS, C.A. Earthworm ecology. New York: CRC press. 2004. 441 p. https://doi.org/10.1201/9781420039719

HARITASH, A. K.; KAUSHIK, C. P.; Biodegradation aspects of Polycyclic Aromatic Hydrocarbons (PAHs): A review. Journal of Hazardous Materials, v. 169, p. 1-15, 2009.

https://doi.org/10.1016/j.jhazmat.2009.03.137

HICKMAN, Z. A.; REID, B. J. Increased microbial catabolic activity in diesel contaminated soil following addition of earthworms (Dendrobaena veneta) and compost. Soil Biology and Biochemistry, v. 40, p. 29702976, 2008. https://doi.org/10.1016/j.soilbio.2008.08.016 
KANALY, R. A.; HARAYAMA, S. Biodegradation of high-molecular-weight polycyclic aromatic hydrocarbons by bacteria. Journal of Bacteriology, v. 182, p. 2059-2067, 2000.

https://doi.org/10.1128/JB.182.8.2059-2067.2000

KANE DRISCOLL, S. B.; MCELROY, A. E. Elimination of sediment-associated benzo[a]pyrene and its metabolites by polychaete worms exposed to 3-methylcholanthrene. Aquatic Toxicology, v. 39, p. 77-91, 1997. https://doi.org/10.1016/S0166-445X(96)00850-8

LIN, S.; LI, H.; HU, F. Effect of earthworm casts on copper uptake by ryegrass in copper polluted soil. Acta Pedologica Sinica, v. 43, p. 911-918, 2006.

MROZIK, A.; PIOTROWSKA-SEGET, Z.; ŁABUZEK, S. Bacterial degradation and bioremediation of polycyclic aromatic hydrocarbons. Polish Journal of Environmental Studies, v. 12, p. 15-25, 2003.

MURATOVA, A. Y.; DMITRIEVA, T. V.; PANCHENKO, L. V.; TURKOVSKAYA, O. V. Phytoremediation of Oil-Sludge-Contaminated Soil. International Journal of Phytoremediation, v. 10, p. 486-502, 2008. https://doi.org/10.1080/15226510802114920

NAJIRAD, S.; GHAVIDEL, A.; ALIKHANI, H. A.; SABBAGH TAZE, E.; GHIASI, S. S.; MOHAMMADI, L. Bioremediation of gasoil by two indigenous bacterial strains in contaminated soils. International Journal of Bioscience, v. 3, p. 71-76, 2013.

PARRISH, Z. D.; BANKS, M. K.; SCHWAB, A. P. Effectiveness of phytoremediation as a secondary treatment for polycyclic aromatic hydrocarbons (PAHs) in composted soil. International Journal of Phytoremediation, v. 6, p. 119-137, 2004. https://doi.org/10.1080/16226510490454803

PARRISH, Z. D.; WHITE, J. C.; ISLEYEN, M.; GENT, M. P. N.; IANNUCCI-BERGER, W.; EITZER, B. D.; KELSEY, J. W.; MATTINA, M. I. Accumulation of weathered polycyclic aromatic hydrocarbons (PAHs) by plant and earthworm species. Chemosphere, v. 64, p. 609-618, 2006.

https://doi.org/10.1016/j.chemosphere.2005.11.003

PENG, R. H.; XIONG, A. S.; XUE, Y.; FU, X. Y.; GAO, F.; ZHAO, W.; TIAN, Y. S.; YAO, Q. H. Microbial biodegradation of polyaromatic hydrocarbons. FEMS Microbiology Reviews, v. 32, p. 927-955, 2008. https://doi.org/10.1111/j.1574-6976.2008.00127.x

PICKARD, M. A.; ROMAN, R.; TINOCO, R.; VAZQUEZ-DUHALT, R. Polycyclic aromatic hydrocarbon metabolism by white rot fungi and oxidation by Coriolopsis gallica UAMH 8260 laccase. Applied and Environmental Microbiology, v. 65, p. 3805-3809, 1999.

Pilon-Smits, E. Phytoremediation. In: Annual Review of Plant Biology, 2005. 15-39 p.

REILLEY, K. A.; BANKS, M. K.; SCHWAB, A. P. Organic chemicals in the environment: dissipation of polycyclic aromatic hydrocarbons in the rhizosphere. Journal of Environmental Quality, v. 25, p. 212-219, 1996. https://doi.org/10.2134/jeq1996.00472425002500020002x

https://doi.org/10.2134/jeq1996.252212x

ROBSON, D. B.; KNIGHT, J. D.; FARRELL, R. E.; GERMIDA, J. J. Ability of Cold-Tolerant Plants to Grow in Hydrocarbon-Contaminated Soil. International Journal of Phytoremediation, v. 5, p. 105-123, 2003. https://doi.org/10.1080/713610174

SCHEU, S. Effects of earthworms on plant growth: Patterns and perspectives. Pedobiologia, v. 47, p. 846-856, 2003. https://doi.org/10.1016/S0031-4056(04)70279-6

https://doi.org/10.1078/0031-4056-00270 
SPARKS, D. L.; PAGE, A. L.; HELMKE, P. A.; LOEPPERT, R. H.; SOLTANPOUR, R. N.; TABATABAI, M. A.; JOHNSON, C. T.; SUMNER, M. E. Methods of Soil Analysis: Chemical Methods. ASA-CSSA-SSSA, 1986.

SVERDRUP, L. E.; KROGH, P. H.; NIELSEN, T.; KJÆR, C.; STENERSEN, J. Toxicity of eight polycyclic aromatic compounds to red clover (Trifolium pratense), ryegrass (Lolium perenne), and mustard (Sinapsis alba). Chemosphere, v. 53, p. 993-1003, 2003. https://doi.org/10.1016/S0045-6535(03)00584-8

TAKÁCS, T.; BIRÓ, B.; VÖRÖS, I. Arbuscular mycorrhizal effect on heavy metal uptake of ryegrass (Lolium p erenne L.) in pot culture with polluted soils. In: HORST, W. J.; SCHENK, M. K.; BÜRKERT, A.;

CLAASSEN, N.; FLESSA, H.; FROMMER, W. B.; GOLDBACH, H.; OLFS, H. W.; RÖMHELD, V.;

SATTELMACHER, B.; SCHMIDHALTER, U.; SCHUBERT, S.; V. WIRÉN, N.; WITTENMAYER, L. (Ed.)

Plant Nutrition: Food security and sustainability of agro-ecosystems through basic and applied research.

Springer Netherlands, Dordrecht, 2001. 480-481 p.

WANG, D.; LI, H.; WEI, Z.; WANG, X.; HU, F. Effect of earthworms on the phytoremediation of zincpolluted soil by ryegrass and Indian mustard. Biology and Fertility of Soils, v. 43, p. 120-123, 2006. https://doi.org/10.1007/s00374-006-0075-8

WILSON, S. C.; JONES, K. C . Bioremediation of soil contaminated with polynuclear aromatic hydrocarbons (PAHs): A review. Environmental Pollution, v. 81, p. 229-249, 1993. https://doi.org/10.1016/02697491(93)90206-4

XIAO, Y. P.; SHAO, Y. F.; SHEN, S. Y.; YIN, R.; LIN, X. G.; ZHANG, J.; BAI, J. F.; CHEN, Y. C. Effect of arbuscular mycorrhizal fungi and earthworms on phytoremediation of as-contaminated soils using maizet.

Journal of Ecology and Rural Environment, v. 26, p. 235-240, 2010.

ZEINALI, M.; VOSSOUGHI, M.; ARDESTANI, S. K. Degradation of phenanthrene and anthracene by Nocardia otitidiscaviarum strain TSH1, a moderately thermophilic bacterium. Journal of Applied Microbiology, v. 105, p. 398-406, 2008. https://doi.org/10.1111/j.1365-2672.2008.03753.x 